\title{
Ukryte kamery Stanisława Barei
}

Images

vol. XIV/no. 23

Poznań 2014

ISSN 1731-450X

W roku 1949 Stanisław Bareja rozpoczyna studia na Wydziale Reżyserii (wówczas: Realizatorskim) w Państwowej Wyższej Szkole Filmowej w Łodzi. Niestety, zrealizowana dziewięć lat później etiuda dyplomowa Gorejace czapki - poczęta z ducha Gogolowskiego Rewizora - nie zostaje ze względów cenzuralnych przyjęta, a formalne ukończenie studiów odwleka się o kilkanaście lat. Jest rok 1974, gdy reżyser (z niemałym już dorobkiem) finalizuje tę kwestię, przedstawiając w roli filmu dyplomowego Męża swojej żony (1960; pełnometrażowy debiut Stanisława Barei), dostarczając jednocześnie pisemną pracę teoretyczną, zatytułowaną Zagadnienia realizacji filmów z ukrytej kamery stanowiacych część telewizyjnych programów rozrywkowych. Liczący 22 strony maszynopis[1], mimo że powstały wyłącznie dla dopełnienia uczelnianych formalności (zakończonych, dodajmy od razu, zdobyciem przez twórcę wyższego wykształcenia), po latach ujawnia swe niezaprzeczalne walory - na trzech przynajmniej płaszczyznach.

Jak pisze Bareja, podstawowym punktem odniesienia jego pracy jest 12 krótkich metraży, wykorzystujących technikę ukrytej kamery, zrealizowanych przez niego w roku 1972 wspólnie z Jackiem Fedorowiczem (i Pawłem Minkiewiczem za kamerą). Warto to jednak uściślić o informacje, które w samej rozprawie się nie znalazły. Otóż, wspomniane produkcje stanowić miały element składowy programu rozrywkowego Tu Telewizja Warszawa w Programie 5, o którym Jacek Fedorowicz (współautor i twórca komentarzy do scen z ukrytą kamerą) mówi:

Program miał być czymś w rodzaju „niby telewizji” wewnętrznej z wiadomościami, reportażami, wywiadami, poradnikami, ale nie było to pomyślane jako parodia telewizji, to był tylko chwyt formalny. Program miał mieć pięć długich odcinków i tyle materiału nakręciliśmy, a po cięciach cenzorskich został jeden krótki odcinek, dość bezsensowny, i to zostało wyemitowane[2].

[1] Drobnej weryfikacji wymaga więc fragment książki Macieja Replewicza Stanisław Bareja. Król krzywego zwierciadła, w której czytamy:

„Spóźnione działania edukacyjne zbiegły się w czasie $\mathrm{z}$ realizacją siódmego filmu długometrażowego [chodzi o Nie ma róży bez ognia - P.P.]. Nie było czasu na rozpisywanie się.
Wartość historyczna
- Jaka jest minimalna objętość pracy? - zapytał Bareja w dziekanacie.

- Siedemnaście stron - brzmiała odpowiedź.

Praca liczy dokładnie siedemnaście stron" (M. Replewicz, Stanisław Bareja. Król krzywego zwierciadła, Wydawnictwo Zysk i S-ka, Poznań 2009, s. 161).

[2] Ibidem, s. 377. 
Dziś - w kontekście zarówno cenzuralnych decyzji sprzed lat, jak i trudności w precyzyjnym ustaleniu, kiedy doszło do emisji programu/ co dokładnie zostało wyemitowane[3] - można podejrzewać, że na ekrany trafił ostatecznie nikły procent $z$ opisywanych w pracy krótkich filmów. Tym cenniejsze zatem okazuje się świadectwo pisane (nawet jeśli nie pojawia się usystematyzowany spis owych 12 produkcji, nie wszystkie opatrzone zostają konkretnym tytułem i nie zawsze udaje się jednoznacznie rozstrzygnąć, czy referowany przez autora przykład stanowi wyłącznie hipotetyczne exemplum, czy jest to pomysł wcielony w życie).

\section{Wartość praktyczna}

Zgodnie z tytułową obietnicą, Stanisław Bareja koncentruje się w tekście na aspekcie realizacyjnym filmów z ukrytą kamerą. Rekonstruowany przez niego proces powstawania produkcji tego typu składa się z czterech etapów: (1) opracowanie założeń inscenizacyjnych, (2) okres przygotowawczy, (3) zdjęcia, (4) montaż i udźwiękowienie. Praktyka wykonawcza pozwoliła reżyserowi zilustrować kolejne podpunkty odpowiednimi przykładami, ale też przyniosła ze sobą całe spektrum zapamiętanych trudności, często zmuszających do modyfikacji pierwotnych „założeń inscenizacyjnych” - i o tym również często pisze Bareja. Jest to tym ciekawsze, że - jak wspomina sam reżyser - jedyną wcześniejszą w Polsce próbę wykorzystania ukrytej kamery (na cele telewizyjnej rozrywki) przypisać można programowi reżyserowanemu przez Jerzego Gruzę[4]. W dużym więc stopniu Bareja do spółki z Fedorowiczem przecierali na krajowym gruncie fabularno-dokumentalnej rejestracji filmowej nowy, niełatwy szlak. Cóż trudnego, zdawałoby się, w obserwowaniu z ukrycia ludzi postawionych w niecodziennej sytuacji - w rzeczywistości proces okazuje się znacznie bardziej skomplikowany. Jak zauważył Allen Funt, pionier amerykańskich programów telewizyjnych typu Candid Camera, złożonych z krótkich scen podpatrzonych ukrytą kamerą [5]:

Najpierw potrzeba bardzo wielu korekt [pierwotnego pomysłu - P.P.], by widzowi zaproponować coś wiarygodnego, a obiekt dowcipu zaangażował się w zaaranżowaną sytuację. Wymagana jest też taka sceneria, która pasować będzie do scenariusza i wyda się sensowna widowni (nawet jeśli inne wrażenie odniesie bohater filmu)[6].

[3] Szerzej o tej kwestii - zob. „Załącznik” do tego tekstu.

[4] Choć w pracy nie pada w tym kontekście żadna konkretna nazwa, chodzi z pewnością o realizowane w latach 6o. Poznajmy się (scenariusze kolejnych odcinków, oprócz samego Gruzy, pisali też Jacek Fedorowicz i Bogumił Kobiela). „Kręciliśmy z Kobielą i Fedorowiczem Poznajmy się i robiliśmy, między innymi, prowokacyjne wywiady z dziećmi. Na przykład: zwracaliśmy się do dziewczynki lub chłopca, zmieniając im płeć. "Jak masz na imię, chłopczyku?» - pytaliśmy dziewczynkę. Dziecko protestowało, używając bardzo zabawnych argumentów" (J. Gruza,
40 lat minęło jak jeden dzień, Czytelnik, Warszawa 1998, s. 131).

[5] Premiera programu - wtedy zatytułowanego tak jak prowadzona wcześniej przez Allena Funta audycja radiowa, czyli Candid Microphone - odbyła się 10 sierpnia 1948 roku w sieci ABC. Największa popularność Candid Camera (nazwa pojawiła się w roku 1949) przyszła wraz z latami 6o. i przenosinami do sieci CBS (1960-1967).

[6] Cyt. za: M. Loomis, Candid Camera, w: Encyclopedia of Television, vol. 1, ed. H. Newcomb, FitzroyDearborn, New York 2004, s. 443 [to i kolejne tłumaczenia w tekście - P.P.]. 
O wszystkich tych kwestiach (i kilku innych, związanych m.in. z trudnościami sprzętowymi oraz reżyserskim prowadzeniem - używając określenia konsekwentnie stosowanego w pracy - „naszego człowieka”, czyli prowokującego w większości odcinków ekranowe zdarzenia „aktora”) pisze również Stanisław Bareja, nierzadko zawężając narrację do poziomu istotnych detali. Tak dzieje się choćby w kontekście zdradzania kulis realizacji scenki Lepiące papiery, w której zdezorientowanym użytkownikom klatki schodowej przylepiały się do butów wyłożone na podłodze tytułowe papiery.

Znalezienie właściwego kleju - opisuje reżyser - zajęło kilka dni, ponieważ kolejno dostarczane próbki albo nie miały dostatecznej przylepności, albo przeciwnie: groziły uszkodzeniami obuwia lub ich niepokojący wygląd z daleka ostrzegał potencjalne ofiary.

Bill Yesil (New York University), odnosząc się do programu Candid Camera, konstatuje:

Widzom oglądającym na ekranie przygotowane sztuczki przychodziło na myśl, że także ich może spotkać coś podobnego. Taka świadomość oraz fakt wkroczenia kamer do codziennego życia przyczyniły się być może do zwiększonej uwagi, jaką ludzie zaczęli poświęcać swojemu zachowaniu w przestrzeni publicznej. Program Candid Camera byłby zaś prawdopodobnie pierwszym, który do przypominającej scenę codzienności wprowadził samo-nadzór (self-scrutiny) oraz samo-inwigilację (self-surveillance) [7].

Znacznie szerzej niż tylko przez pryzmat telewizyjnej rozrywki postrzegał swoją działalność sam Allen Funt, który - zanim trafił do świata mediów - asystował przez pewien czas na Cornell University (w stanie Nowy Jork) wybitnemu psychologowi społecznemu Kurtowi Lewinowi. Funt był zdania, że Candid Camera to nie tylko szansa wydobycia z ludzi skrywanych na ogół cech osobowości, ale też pożyteczna lekcja dla każdego widza przed telewizorem:

Wiele pokoleń uczono, jak wygląda zaaranżowany świat sceny i ekranu. Nasza publiczność, by zaakceptować „ukryte badania” (candid studies), musi się w dużym stopniu tego oduczyć. Wystarczy jednak rozejrzeć się wkoło i posłuchać, by zyskać potwierdzenie dla naszych odkryć[8].

Przywołane refleksje to tylko wyrywkowe przykłady, jak myślenie o rozrywkowych filmach realizowanych z ukrytą kamerą wykraczać może poza prostą konstatację, iż ich jedynym celem jest rozbawienie widza. Bareja, czego dowodzi jego praca, nie lekceważył tej problematyki, sięgającej poza kwestie stricte realizacyjne.

[7] B. Yesil, Reel Pleasures: Exploring the Historical Roots of Media Voyeurism and Exhibitionism, "Counterblast: The e-Journal of Culture and Communication" 2001 (November), vol. 1, no. 1, s. 3 [online], <http://pdf.aminer.org/ooo/306/377/voyeurism_exhibitionism_and_privacy_on_the_internet. pdf>[dostęp: 2 lipca 2014].
Wartość myślowa 
Ukryta kamera - pisał - ma [...] rzeczywiście duże wartości poznawcze i traktowanie jej jedynie jako figla płatanego bezbronnym ludziom przez zorganizowaną grupę, dla wyszydzenia ich przed olbrzymim audytorium, byłoby spłyceniem i zwulgaryzowaniem możliwości artystycznych, jakie stwarza.

Bareja - co oczywiste w świetle obietnicy tytularnej - nie czyni tego tematu dominującym w swej rozprawie; nie rezygnuje jednocześnie z zasygnalizowania innych wątków, które wydają mu się istotne, choć niekoniecznie ściśle mieszczą się w pojęciu realizacji. Świadczące o tym akapity można by zgrupować wokół dwóch zagadnień:

\section{Mechanizm rozśmieszania}

Bareję interesuje proces „wywoływania określonych, zamierzonych emocji”, w tym wypadku: będących efektem zetknięcia widza ze sceną nakręconą z wykorzystaniem ukrytej kamery. Skutecznie rozbawić - to jasne, ale przy użyciu jakich metod? typowych dla filmowego gagu czy opowiadanego dowcipu? „Jednym z podstawowych prawideł wywoływania śmiechu jest pokazanie obiektu ośmieszanego w sposób, który w widzu wytworzy przekonanie o własnej przewadze (fizycznej lub intelektualnej) nad przedstawionym osobnikiem" - stwierdza reżyser, dostrzegając przy okazji w opisywanych przez siebie działaniach świetną szkołę filmowego rzemiosła (cenną zwłaszcza w okolicznościach piętrzących się trudności i ograniczeń sprzętowych).

\section{Dylematy etyczne}

Jak pisze Amy Loomis, twórca amerykańskiej Candid Camera „niszczył każdy materiał, który ostatecznie wydawał mu się nie na miejscu lub zbyt głęboko wkraczał w prywatne życie bohaterów”[9] - od takich decyzji nie byli wolni również Bareja z Fedorowiczem. Ten pierwszy pisze $z$ wiele mówiącą szczerością: „Nierozwiązaną do tej pory kwestią jest pokazywanie na ekranie ludzi nieuprzedzonych o udziale w zdjęciach”. O tym, jak „problematyczne” (ale czy zawsze zaskakujące?) może to przynieść efekty, przekonała twórców choćby scena w Supersamie, gdzie podstawiony „nasz człowiek” proponował klientom pomoc w drobnych kradzieżach, co kilkakrotnie spotkało się z ich aprobatą - rejestrujących to materiałów filmowcy postanowili nie wykorzystywać na ekranie. Tym razem powód tego był dość oczywisty: chodziło o „konsekwencje, jakie zapewne spotkałyby niedoszłych przestępców (a następnie prawdopodobnie również realizatorów)”. Łatwo jednak wyobrazić sobie okoliczności, gdy ukryta kamera zmusza do decyzji znacznie trudniejszych.

Sensowność publikowania pracy magisterskiej Stanisława Barei (po ponad 40 latach od jej obrony) wydaje się niepodważalna. Oto okazja,

[9] M. Loomis, Candid Camera, op. cit., s. 443. 
by - mając za przewodnika samego reżysera - przyjrzeć się temu etapowi jego filmowej działalności, który (co nie może dziwić choćby w kontekście dostępności materiałów źródłowych) do tej pory pozostawał i zapewne pozostanie w cieniu kinowych dzieł pełnometrażowych.

Sądząc z listów nadchodzących do telewizji po emisji moich programów, w których prezentowałem także filmy z ukrytą kamerą, utwory te cieszą się dużą popularnością, chociaż jest jasne, że różnią się niekorzystnie od reszty programu niską jakością obrazu i dźwięku, a nieświadomi wykonawcy ról $\mathrm{w}$ takich produkcjach są zestawiani z najpopularniejszymi zawodowymi aktorami zawodowymi. Jakie są przyczyny tego zjawiska?

- pyta Stanisław Bareja. On też próbuje przekonująco na to pytanie odpowiedzieć.

\section{Załącznik 1}

Niejasno przedstawia się kwestia dat emisji programu Tu Telewizja Warszawa w programie 5. Pewny jest właściwie tylko rok (1972) - na poziomie miesięcy i konkretnych dni zaczynają rodzić się wątpliwości. Gdyby pokusić się o sformułowanie kilku hipotez na temat zarówno losów emitowania, jak i ostatecznej konstrukcji programu Barei i Fedorowicza, brzmiałyby one tak:

a) po pierwsze, program Tu Telewizja Warszawa $w$ programie 5 przed pierwszą emisją zaprojektowany został jako dwuczęściowy. Wersję tę potwierdza zachowana w archiwum Jacka Fedorowicza rozpiska programu, podzielonego właśnie na „część I” i „część II”. O tym, że pierwotne zamierzenia były znacznie szersze, przekonują nie tylko cytowane już słowa wspomnianego Jacka Fedorowicza (iż nakręconego materiału starczyłoby na „pięć długich odcinków”), ale i kolejny dokument $\mathrm{z}$ jego archiwum, szkicujący wersję trzyodcinkową. Za postępującymi skrótami stały, rzecz jasna, względy cenzuralne;

b) po drugie, w wersji „optymalnej” do emisji programu doszło w roku 1972 czterokrotnie: 20 (część I) i 21 maja (cześć II) oraz 1 (część I) i 29 października (część II), przy czym pokazy jesienne uznać trzeba za powtórkę tych majowych, co więcej - na podstawie programu telewizyjnego da się wywnioskować, iż oba odcinki zostały skrócone (zwłaszcza drugi - w pierwotnej wersji trwał około godziny, po skrótach: niecałe trzydzieści minut; przychyla się do tych ustaleń Jacek Fedorowicz, który w kontekście machinacji cenzuralnych pisze o emisji z 29 października: „To najpewniej po nadaniu tego drugiego [odcinka] zapamiętałem sobie, że skompromitowano nas nadaniem ścinków czegoś, co zapowiadało się jako całkiem niezły cykl"[10]). Tu jednak istotna uwaga: całkowita pewność emisji dotyczy właściwie tylko dwóch dat (20 maja oraz 1 października):

[10] Z korespondencji z Jackiem Fedorowiczem (list Z 21 sierpnia 2014 r.) - archiwum prywatne (P.P.). 


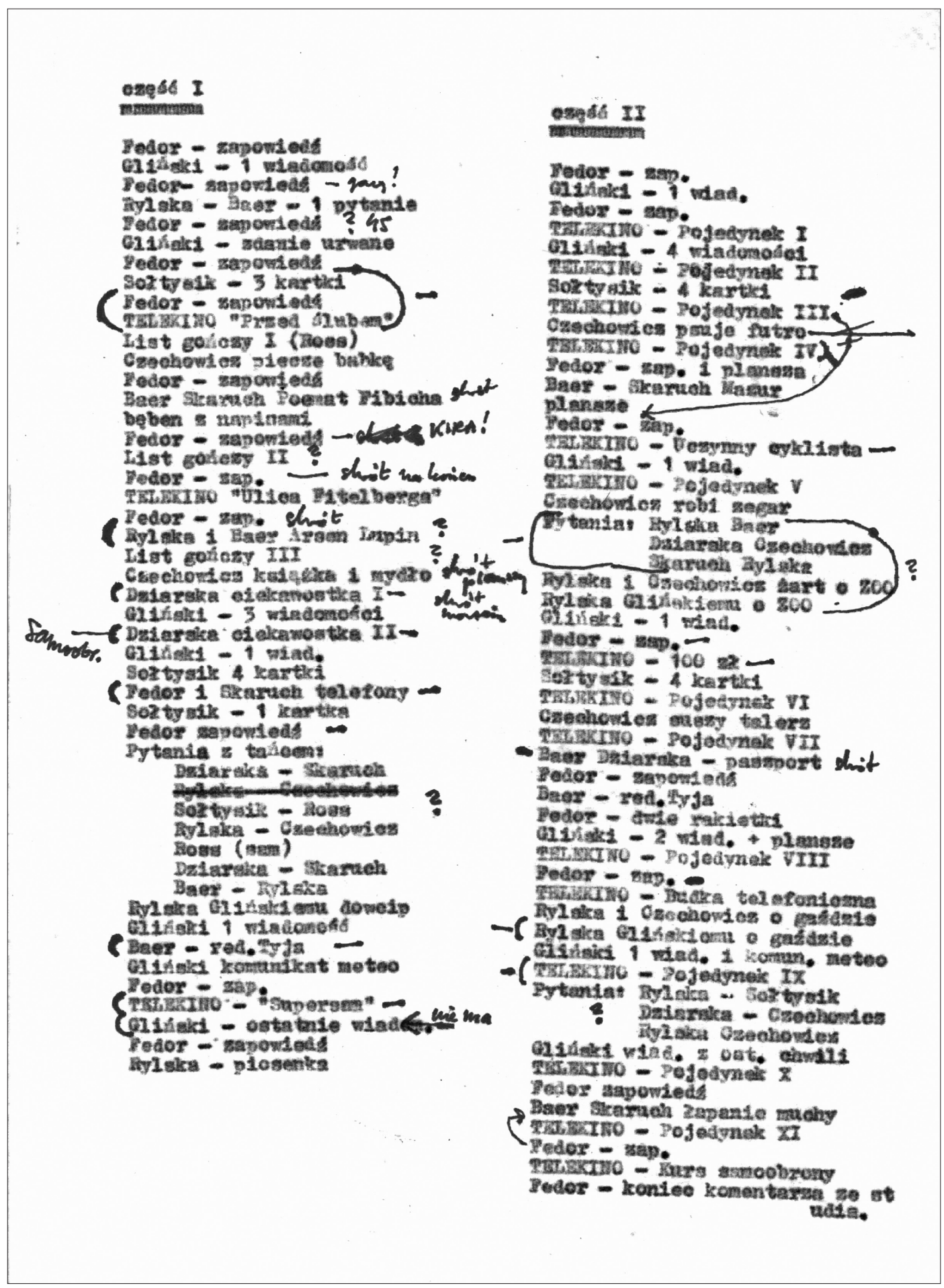


1

wiadomości: grubi, mleko muzyczne: pianista wsp6ine krzesełko

ukryta $k m_{0}:$ na drabinie wywiad: $z$ kucem seffero filmy: kucharze

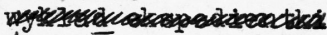
dzicy I

sport: Echa olimpijskie Poradnik Bramkarza

Mietek: gareta skecz operacja. planne:

czas bardzo na oko: 44

telekino wchodzi 7 razy

POSTEP

kAZENAARR

PIANISIA

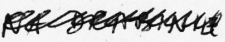

S2NCto

WI ADOROIC PEZNE SRUBS!

WCDR

KUCA.AREE WAD.

OPERACFA

NA DRABINIE.

IEKSTEDIENTIA

II WDADorioies

SPONT ECHA BPATKARR MIETTK GAZETA Listy

D2ICY 1

putócoxa
2

3

ser. winda

cygan aria Baer Rylska

flecista

cyganka $\leftarrow$ ?

$\longrightarrow$ sitasha

2 maigm $z$ Rotonem

Dziura w dachu

$52<\quad$ Abstyhent 4 '45

dzicy II

E

tekst o. umasowie niu TV Powiśle -boks

EXPEDIENTKA

inoshathe

PAC HonAl12

Margaryme

40

pestauracsa

zupa

ostatnia 'szansa

Lidocahi (W-va latem)

45

ewentualnie:
rac jonalizator $5^{1} 2$
wtedy czas 44

Prazy<smiles>CC(C)(C)[Si](C)(C)C(C)(C)C</smiles>

WHEP

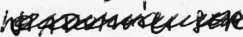

Kalendarz

PACZONALIZATOR

WTADOTOJ'L SER

TRUSWAWKA

in ADOThoici

SPORT TEKST

CMGAN

\section{LISTY}

PODNeyatacs

SI ACEACA

SItACCNA

Sita

nuargaryu.

2

WYMNAD 2 MAEYM

HIETEK radioderho

Kon'cout?

TMtí UKA

\section{ho}

WHEEP

GADAME

- CMGANKA

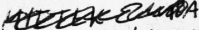

c WIAOONOSCI PAPIERY.

WIADOMOSCI DACHM.

WIAD.P

MISTEK ZUPA.

APSTH NENT.

- ARI A p kalendarzp O मTATUIA sLANSH.

REATDOM

RESTAWRACJA.

- wiad linda

- Flecista

TV POWISLE-ROKS. GADANTE

TYtóUKA

Szkicowy scenariusz trzyodcinkowej wersji programu Tu Telewizja Warszawa w programie 5 (źródło: archiwum prywatne J. Fedorowicza) 
- 20 maja - o zaplanowanym na ten dzień pokazie wspominają w swoim liście do telewizji Bareja i Fedorowicz (list datowany jest na 6 maja; źródło: arch. pryw. J. Fedorowicza), odnotowują go wszystkie sprawdzone programy telewizyjne, zaś w „Szpilkach” (wydanie z 4 czerwca) ukazuje się krótka recenzja programu; niestety, ta ostatnia nie precyzuje, ile odcinków jest jej przedmiotem, co w obliczu rozbieżności odkrytych w programie telewizyjnym na 21 dzień maja każe się zastanowić, czy ówczesna emisja drugiej części programu w ogóle miała miejsce

- 1 października - tu mocne dowody stanowią dwa artykuły prasowe z „Gazety Olsztyńskiej” i „Gazety Robotniczej” - datowane (odpowiednio) na 6 października 1972 r. (piątek) oraz 7-8 października 1972 r. (sobota-niedziela). Oba teksty są recenzjami telewizyjnej „sztuki rozrywkowej, tzw. lekkiej muzy”[11] (by zacytować jednego z autorów), zaprezentowanej na małym ekranie ok. tygodnia wcześniej. O programie Barei i Fedorowicza wspomina się w kontekście niedzieli (to właśnie 1 października). Ponownie jednak rodzi się pytanie o część II - nie dość, że mija niemal miesiąc, nim pojawiają się na jej temat wzmianki w kilku programach telewizyjnych, to dodatkowo przynajmniej w dwóch źródłach ramówki na 29 października („Kurier Polski”, „Trybuna Ludu”) nie ma o Tu Telewizja Warszawa $w$ programie 5 żadnej wzmianki;

c) po trzecie, wydaje się, iż krótkie filmy Barei i Fedorowicza realizowane z ukrytą kamerą zaprezentowane zostały widzom wyłącznie w ramach produkcji Tu Telewizja Warszawa $w$ programie 5; nie odnaleziono (jak dotąd) śladów emitowania ich poza tym kontekstem.

By lepiej zorientować się w zawikłanych losach ekranowych programu Tu Telewizja Warszawa $w$ programie 5, skonstruowana została poniższa tabela. Odtwarza ona jego (nie)obecność na łamach wybranych czasopism, wydanych w roku 1972. W przypadku „Radia i Telewizji”, „Kuriera Polskiego”, „Głosu Wielkopolskiego” i „Trybuny Ludu" źródłem informacji były programy telewizyjne[12], w pozostałych wypadkach okazały się nim rubryki z zapowiedziami konkretnych punktów ramówki (lub krótka recenzja - casus „Szpilek”). Podane ramy czasowe oznaczają początek nadawania programu Barei i Fedorowicza oraz kolejnej pozycji w rozkładzie dnia. Swoją drogą, warto zwrócić uwagę na nierzadkie dysharmonie w tym względzie - bywa tak, że ten sam odcinek ma trzy różne godziny emisji (1 października - 17.35, $17.45,18.35)$.

[11] PIK, Poezja i obyczaje, „Gazeta Robotnicza” 1972, nr 40, s. 7.

[12] Wymienione tytuły nie wyczerpują, rzecz jasna, ówczesnych źródeł telewizyjnej ramówki, są jednak reprezentatywne dla rozbieżności w zapowiedziach programu Barei i Fedorowicza (innymi słowy - programy tv $\mathrm{z}$ innych przejrzanych czasopism pokrywały się z którymś z tych przedstawionych w tabeli). 


\begin{tabular}{|c|c|c|c|}
\hline & 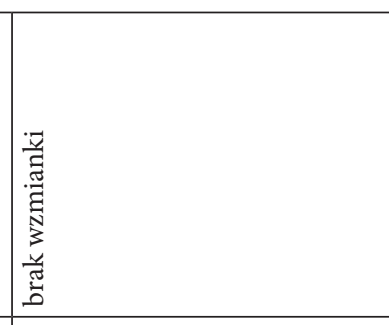 & 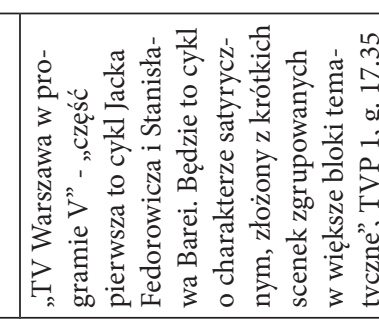 & 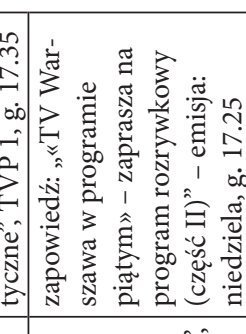 \\
\hline & & 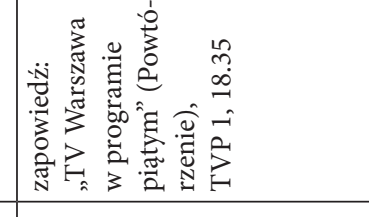 & 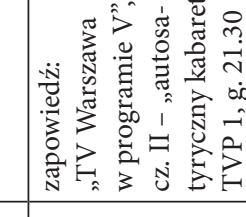 \\
\hline 告 & 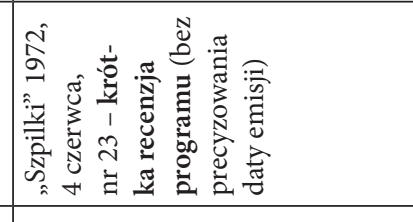 & & 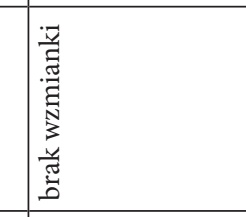 \\
\hline 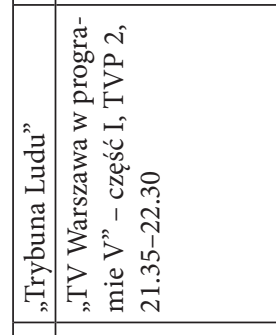 & 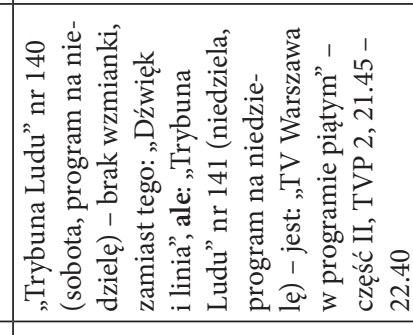 & 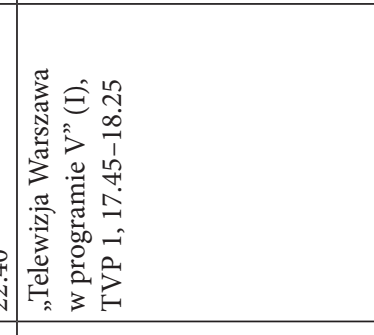 & 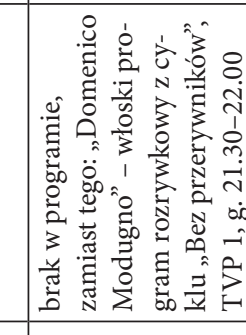 \\
\hline 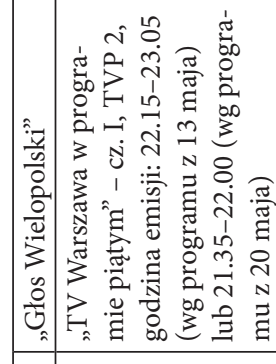 & 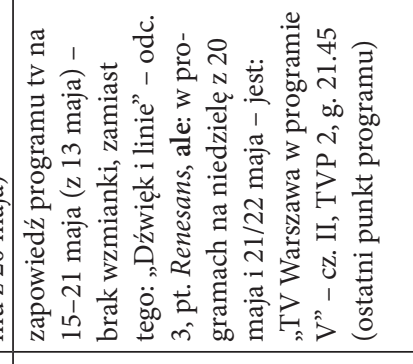 & 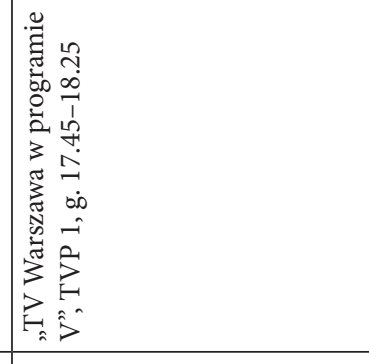 & 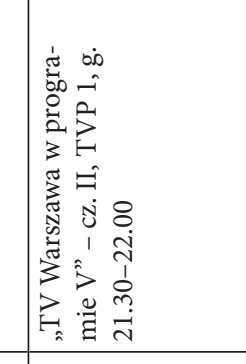 \\
\hline 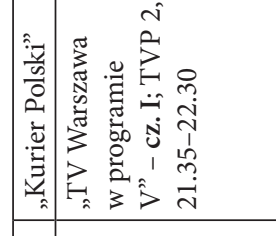 & 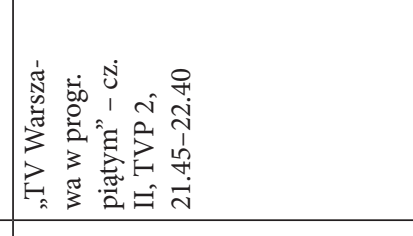 & 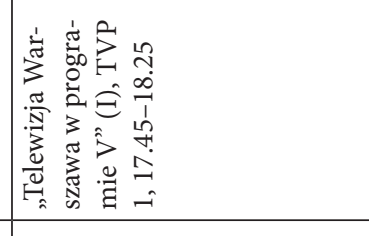 & 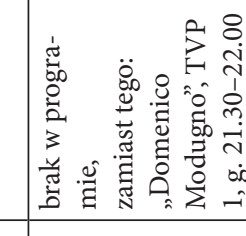 \\
\hline 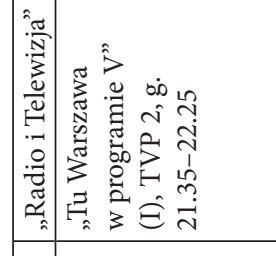 & 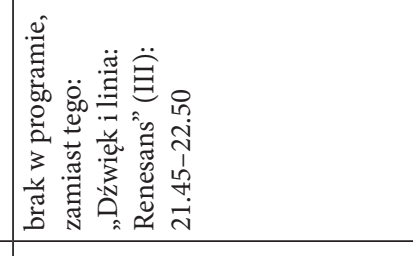 & 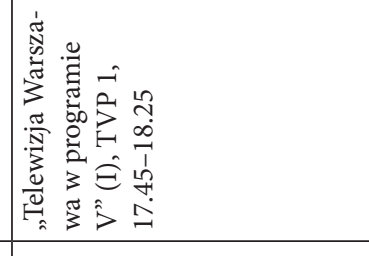 & 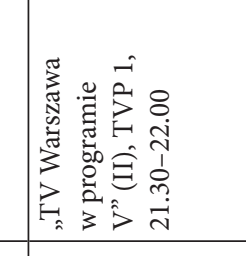 \\
\hline 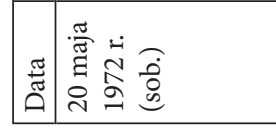 & 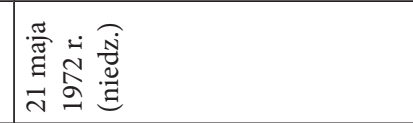 & 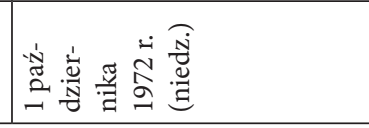 & 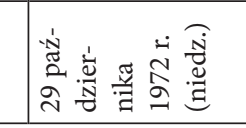 \\
\hline
\end{tabular}




\section{Załącznik 2}

Jak odnotowuje w swojej pracy magisterskiej Stanisław Bareja, zrealizował on w sumie 12 krótkich filmów z wykorzystaniem ukrytej kamery. Bez większych wątpliwości odtworzyć dziś można pomysły na dziesięć $\mathrm{z}$ nich (podane tytuły traktować trzeba raczej roboczo; czasami - co zaznaczono w poniższym wykazie - trudno było na podstawie tekstu Stanisława Barei i innych archiwaliów ustalić jedną wersję danego tytułu).

\section{$\underline{\text { Szk } ¥ 0}$}

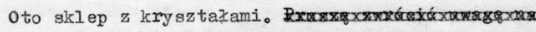

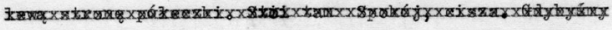

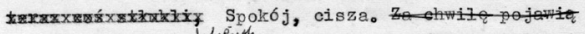
Gdy projejaie obok półki, pociągniemy za sznureczek $i$ sciągniemy coś tłukę́cego. To nixribst

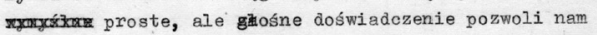
zbadać reakcję klienta. Czy będzie poczuwaz się do winy? Jest klientka, proszę zwrócić uwage na lewąstronę półki.

Brzęk。 Reakcja pierwsza to reakcja - powiedział bym - minimalna, znamionująca charakter opanowany, chciazo by się rzec, osobę o żelaznych nerwach. Reakcja zakończona chwilą głęboki go namyału: co się właściwie stało? Reakeja druga prawidłowa. Ten pan wie że nie strącił.

Ta sprawa go po prostu nie interesuje.

Ten pan reprezentuje w naszym filmie dociekliwość Dociekliwość $i$ wytrwałość w tropieniu przyczyn, która w efekcie doprowadza go do zdemaskowania mechanizmu.

Tak? Tak.

Następne reakcje, to będzie niewinność walozęca. Nie spadzo.

To eharakterystyczne dla ogromnej większości reakcji. Pierwsza myśl - udowodnić swoja niewinność. Co prawda istnieje zasada, że oskarżony jest niewinny do chwili kiedy nie udowodni mu się winy, ale...okazuje się, że podśriadomość, czy może doświadczenie nakazuje nam stosować zasadę odwrotną. Cheerny udowodnić naszę niewinność $i$ to natychmiast. I im więcej będziemy mieli świadków, tym lepiej.
Komentarz autorstwa Jacka Fedorowicza do krótkiego filmu Szkło, zrealizowanego z użyciem ukrytej kamery (źródło: archiwum prywatne J. Fedorowicza)
1. Szkło - obserwacja reakcji klientów sklepu z kryształami, którzy (nie wiedząc o działaniu ekipy filmowej) sądzą, że właśnie stłukli jeden $\mathrm{z}$ wystawionych przedmiotów

2. Dziewczyna w mini na drabinie - obserwacja przechodniów mijających drabinę, na której stoi „nasz człowiek” ekipy filmowej, czyli kuso ubrana dziewczyna (ślad tego pomysłu znajduje się na jednej z rozpisek programu Tu Telewizja Warszawa...; S. Bareja wspomina w pracy o filmie Panienka $z$ ksiązką: tu wzrok przechodniów przyciąga wydekoltowana kobieta na przystanku - może to być albo inny wariant tego samego pomysłu, który ewoluował w trakcie realizacji, albo zupełnie osobna produkcja)

3. Cyganka-wróżbitka / Wróżby cygańskie - obserwacja procesu ulicznego wróżenia

4. Klejące siępapiery / Lepiące papieryobserwacja idących klatką schodową ludzi, którym leżące na podłodze papiery przyklejają się do butów

5. Dziewczyna-siłaczka - obserwacja reakcji ludzi, widzących, jak mała dziewczyna bez trudu unosi (olbrzymi w ich mniemaniu) ciężar znajomości” (S. Bareja) przez „naszego człowieka”, wyjątkowo wygadanego młodzieńca

7. Koszykowa zmieniona na Fitelberga / Nowa nazwa - obserwacja reakcji przechodniów, którzy - w trakcie objaśniania trasy przybyszowi spoza Warszawy - orientują się, że dobrze im znana ulica najwyraźniej zmieniła nazwę

8. Supersam - obserwacja klientów sklepu, którym „nasz człowiek” proponuje współpracę przy złodziejskim procederze

9. 100 złotych / Połówka banknotu - obserwacja znalazców połówki 10o-złotowego banknotu, proszonych o odsprzedanie go „naszemu człowiekowi" po mocno zaniżonej cenie

10. Budka telefoniczna - obserwacja korzystających z budki telefonicznej, którym po wejściu do niej pozostaje w dłoni klamka 